\title{
Isolation of Cellulose-Degrading Bacteria from Luwu Timur in Oil Palm Empty Fruits Bunch
}

\author{
Maswati Baharuddin*, Irma Rahayu, Amalyah Febryanti \\ Department of Chemistry, Faculty of Science and Technology, Universitas Islam Negeri \\ Alauddin Makassar, South Sulawesi \\ *E-mail: bmaswati@gmail.com
}

Received: 10 September 2021; Accepted: 16 November 2021; Published: 15 December 2021

\begin{abstract}
The oil palm empty fruit bunch (OPEFB) is one of the solid wastes produced by industrial factories. These bunches are the habitat of cellulolytic bacteria. This study aims to identify the morphology and determine the potential microorganisms in degrading oil palm empty fruit bunches waste. The methods used in this study were isolation and observation of bacterial morphology, bacterial screening, degradation test of empty oil palm fruit bunches waste, and enzyme activity test with DNS method using UV-Vis spectrophotometer at a wavelength of $530 \mathrm{~nm}$. A collection of 14 isolates were obtained from the isolation process. We obtained 14 isolates from the sample, the largest clear zone was shown by isolate $S_{10}$. The isolate also exhibited the highest cellulose-degrading activity after 7 days incubation period with a degrading percentage of $13.27 \%$. After incubation for 2 days, the morphological characteristics of the bacteria produced have circular and medium-sized colonies, yellow, colonies wave edges and flat colonies, elevation convex and smooth surface. The resulting enzyme activity was $0.1308 \mathrm{U} / \mathrm{mL}$. Therefore, isolate $S_{10}$ was suspected to have the potential to degrade plastic.
\end{abstract}

Keywords: Cellulase-degrading bacteria; cellulose; DNS method; OPEFB

\section{Introduction}

An Oil palm is a plant that is tolerant of the surrounding environment. There are many oil palm plantations in South Sulawesi, especially in East Luwu. There are many palm oil factories in the area. Every factory process palm oil into crude oil which is then exported only to foreign countries for reprocessing. The fresh fruit will be processed to produce crude oil. In addition to producing oil, these products produce by-products, both in the form of liquids and solids. Liquid waste is waste generated from fruit washing and equipment used when processing palm oil, while solid waste is in the form of oil palm empty fruit bunch (OPEFB).

OPEFB is a very abundant solid waste of palm oil mills. Waste generated by EFB reached 5,050,367.60 tons in 2010 and $5,176,842.53$ tons in 2011. The waste generated by factories will increase every year due to the increasing demand for palm oil nationally (Tarkono and Ali, 2015). If the OPEFB is in a pile within a few days, it will cause an unpleasant odor so that it can pollute the surrounding environment. OPEFB takes a long time to decompose because it contains cellulose (Rahmasita et al., 2017). 
Cellulose is a polysaccharide which is hydrolyzed to produce cellobiose and glucose monomers. A single cellulose molecule is a straight-chain polymer of $\beta$-1,4-glucoside linked by glycosidic bonds (Razie et al., 2011). Cellulose can be degraded using cellulase enzymes. Enzymes can generally be obtained from animals and plants that carry out reactions such as hydrolysis, oxidation, reduction, isomerization, addition, radical transfer, and termination of carbon chains (Supriyatna et al., 2015). In addition to plants and animals, enzymes can also be produced by microorganisms.

Several studies have used microorganisms as cellulase enzymes producer. Ekawati et al. (2012) reported five isolates of the genus Pseudomonas sp. which is able to degrade cellulose very well, namely Cellvibrio sp1. UV3; Cytophaga sp2. UV1, Cytophaga sp2. UV5; Cellvibrio sp2. UV4; and Micrococcus sp. UV2. Purkan et al. (2015) stated that the adaptation phase of Aspergillus niger was reached at 0 to 4 hours, then significant growth or exponential phase was experienced up to 24 hours. The optimum activity of the cellulase enzyme was reached at $\mathrm{pH} 4$ with $0.324 \mathrm{IU} / \mathrm{mL}$.

Murtiyaningsih and Hazmi (2017) isolated from waste soil. The activity of cellulase enzymes is $0.135 \mathrm{nKat}$ with a reducing sugar of $0.0874471 \mathrm{mg} / \mathrm{mL}$. The results obtained are directly proportional to the cellulase activity and reducing sugar content.

Measurement of bacterial activity based on the amount of glucose produced using a UV-Vis spectrophotometer. The absorbance was measured at $540 \mathrm{~nm}$ using the di-nitro salicylic acid (DNS) method (Murtiyaningsih and Hazmi, 2017). DNS can be used to measure reducing sugars formed by microbes and can be applied to sugars that have even low levels (Argo and Yulianingsih, 2013). (Kholis et al., 2019) stated, isolate $C_{9}$ potent to degrade cellulose of biomass of eucalyptus waste. (Rupaedah et al., 2019) reported that the genus of Bacillus can degrade effectively lignin of OPEFB.
As far as the search, there has been no research on cellulose-degrading bacteria in OPEFB Luwu Timur, South Sulawesi. Therefore, this study aims to isolate indigenous bacteria from OPEFB in Luwu Timur and screen cellulose degradation activity.

\section{Methodology}

\section{Materials}

A sample, oil palm empty fruit bunch (OPEFB), originated from the palm oil industry of PPTP XXVIII in Burau District, Luwu Timur Regency. Soil samples were taken from the OPEFB pile. The samples were taken from three different points with 7.0$15.0 \mathrm{~cm}$ in depth.

Carboxymethyl cellulose (Merck, Germany), congo red 1\% (Merck, Germany), yeast extract, glucose, dipotassium phosphate $\left(\mathrm{K}_{2} \mathrm{HPO}_{4}\right)$, potassium nitrate $\left(\mathrm{KNO}_{3}\right)$, magnesium sulfate $\left(\mathrm{MgSO}_{4}\right)$, sodium chloride $(\mathrm{NaCl})$, nutrient agar (NA), nutrient broth (NB), and DNS (3,5-dinitro salicylic acid) reagents.

UV-Vis spectrophotometry Genesys 20 (Varian, USA), cold sentrifugator Z $366 \mathrm{~K}$ (Hermle, Germany), shaker MASQ 7000 (Thermo Scientific, USA), Heraeus incubator (Thermo Scientific, Germany), GmbH oven (Memmert, Germany), yx-280D autoclave (GEA, Germany), laminar airflow isocide 14644-1 (Esco, Singapore), magnetic stirrer (Health, United States), US 200 sieve shaker (Retsch, United States), vortex mixer wizard (Velp Scientifica, Italy).

\section{Procedure}

Isolation of cellulase-producing bacteria

Bacterial isolation was carried out using a spread plate. Before the step, samples were diluted using the dilution method. A sample soil of $1 \mathrm{~g}$ was put into $9 \mathrm{~mL}$ of $85 \%$ $(\mathrm{w} / \mathrm{v}) \mathrm{NaCl}$ solution, then homogenized using a vortex. Dilution series were made up to $10^{-7}$ (Peristiwati et al., 2018). After that, about 0.1 $\mathrm{mL}$ of the sample was taken from dilution of 
$10^{-5}, 10^{-6}$, and $10^{-7}$ were put into Petri dishes that already contained selective media with the distribution method (Murtiyaningsih and Hazmi, 2017). The resulting morphology was inoculated on the same medium using the quadrant line method, then incubated at $37^{\circ} \mathrm{C}$ for 48 hours (Arifin et al., 2019). The morphological observations of isolates include color, shape, edge, elevation, surface, and size. Isolates growing on the surface were observed for color, translucency, elevation, and edges (Talantan et al., 2018).

Screening of cellulolytic activity

All isolated bacteria were grown on CMC agar media and their cellulolytic activity was evaluated quantitatively by measuring the diameter of the clear zone after pouring with $0.1 \%$ congo red. The cellulolytic index can be calculated by using the formula follows (1). The presence of a clear zone shows a positive $(+)$ result due to the degradation of cellulose by the cellulase enzyme (Peristiwati et al., 2018). The clear zone can be measured using a caliper and the difference between the diameter of the medium clear zone and the diameter of the capillary is calculated as the clear zone (Rawway et al., 2018). It is expressed as the Cellulolytic Index (IS) (Ferbiyanto et al., 2015).

$$
C I=\frac{D C Z-D C}{D C} \cdots \cdots
$$

which CI is the cellulolytic index; DCZ is the diameter of the clear zone; $D C$ is the diameter of the colony

Determination of dry weight percentage of OPEFB

The test was carried out to determine the ability to degrade cellulose. It was done using four pieces of OPEFB soaked in detergent for one minute and rinsed with distilled water. Removal of water content was carried out at a temperature of $105^{\circ} \mathrm{C}$ for five hours (Yusnia et al., 2019).

One use of isolates with a high clear zone was inoculated into $25 \mathrm{~mL}$ of CMC liquid media. The incubation of isolates was carried out at room temperature for 24 hours at a speed of $180 \mathrm{rpm}$. A $10 \mathrm{~mL}$ of incubation results were inoculated into $100 \mathrm{~mL}$ of CMC liquid medium. Then, the OPEFB (known as its initial dry weight) was put into the CMC liquid medium. After that, the incubation process was run for 10 days at a speed of 180 rpm (Murtiyaningsih and Hazmi, 2017). After the process, the final dry weight of the OPEFB was known. Furthermore, loss of dry weight could be calculated by using the formula follows (2).

$$
\Delta W(\%)=\frac{W_{i}-W_{f} \ldots \ldots \ldots . .(2)}{W_{i}}
$$

which $\Delta W$ is the loss of dried weight; $W_{i}$ is the initial weight before the degradation process; $W_{f}$ is the final weight after the degradation process

\section{Test of Cellulase Enzyme Activity}

The test was carried out using a 3,5-dinitro salicylic acid (DNS) reagent. A mixture of $1 \%$ CMC and $1 \mathrm{~mL}$ of sample was incubated for 60 minutes at $37^{\circ} \mathrm{C}$ (Talantan et al., 2018). Then the mixture was added with $3 \mathrm{~mL}$ of DNS and heated for 10-15 minutes until a color change occurred. After cooling, the absorbance was measured at $540 \mathrm{~nm}$ using V-Vis Spectrophotometer. The control and blank solutions were also carried out and the absorbances were measured (Murtiyaningsih and Hazmi, 2017).

$$
E A=\frac{[\text { glucose }] \times V_{t}}{R M \times t \times V}
$$

which $E A$ is the enzyme activity $\left(U \mathrm{~mL}^{-1}\right)$; [glucose] is the concentration of glucose; $R M$ is the relative mass ( $\left.\mathrm{g} \mathrm{mol}^{-1}\right)$; $t$ is the time of incubation; $V$ is the enzyme volume $(\mathrm{mL}) ; V_{t}$ is the total enzyme volume $(m L)$

\section{Result and Discussion}

Isolates of cellulose-degrading bacteria from OPEFB

Based on the result, there were A total of five bacterial isolates of 14 isolates were obtained from OPEFB with high cellulolytic activity. The observations were made after two days of incubation for $2 \times 24$ hours. It can be seen in Figure 1. 


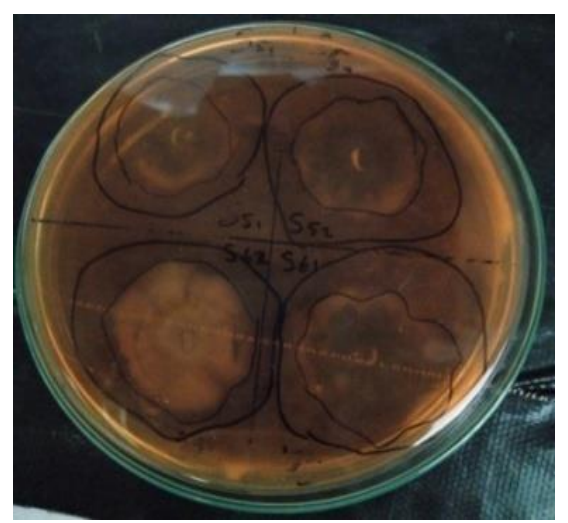

Figure 1. Bacterial colonies growing on CMC media

Characteristic of bacterial isolates can be seen based on the morphology formed. There was a variety of all bacterial morphology. It can be seen in Table 1.

Table 1. The morphology character of bacterial colonies

\begin{tabular}{|c|c|c|c|c|c|c|}
\hline $\begin{array}{l}\text { Codes of } \\
\text { colony }\end{array}$ & Shape & Color & Edge & Elevation & Surface & Size \\
\hline $\mathrm{S}_{1}$ & circle & $\begin{array}{c}\text { slightly } \\
\text { clear white }\end{array}$ & flat & flat & smooth & small \\
\hline $\mathrm{S}_{2}$ & circle & yellowish & flat & convex & smooth & small \\
\hline $\mathrm{S}_{3}$ & circle & $\begin{array}{c}\text { slightly } \\
\text { clear white }\end{array}$ & flat & flat & smooth & big \\
\hline $\mathrm{S}_{4}$ & circle & $\begin{array}{c}\text { slightly } \\
\text { clear white }\end{array}$ & flat & flat & smooth & medium \\
\hline $\mathrm{D}_{3}$ & circle & $\begin{array}{c}\text { slightly } \\
\text { clear white }\end{array}$ & flat & flat & smooth & medium \\
\hline $\mathrm{S}_{5}$ & circle & yellow & flat & convex & smooth & medium \\
\hline $\mathrm{S}_{6}$ & irregular & milky white & flat & umbonate & smooth & medium \\
\hline $\mathrm{D}_{7}$ & irregular & milky white & flat & umbonate & smooth & medium \\
\hline $\mathrm{S}_{7}$ & circle & $\begin{array}{c}\text { slightly } \\
\text { clear white }\end{array}$ & flat & convex & smooth & medium \\
\hline $\mathrm{D}_{1}$ & circle & $\begin{array}{c}\text { slightly } \\
\text { clear white }\end{array}$ & flat & convex & smooth & medium \\
\hline $\mathrm{S}_{8}$ & circle & yellow & wave & convex & smooth & medium \\
\hline $\mathrm{S}_{9}$ & circle & yellow & wave & convex & smooth & medium \\
\hline $\mathrm{S}_{10}$ & circle & milky white & flat & convex & smooth & big \\
\hline $\mathrm{S}_{11}$ & circle & milky white & convex & flat & smooth & small \\
\hline
\end{tabular}

Based on the results, the bacterial colonies obtained grew on CMC agar media. CMC was used because it is a good substrate that can affect the growth of bacteria in producing cellulase (Marina et al., 2018). Furthermore, macroscopic morphological observations were carried out to determine the differences that existed in each different colony. Colonies 
that were different from each other were selected based on colony shape, colony color, colony elevation, colony edge, and colony shape (Nofu et al., 2014).

Cellulolytic Index of Bacterial Isolates

Isolated bacteria that were able to produce a clear zone were measured for their cellulolytic index. It can be worked by comparing the value of the diameter of the clear zone and the diameter of the bacterial colony (Nababan et al., 2019).

Based on Table 2, there were only five isolates that were able to produce clear zones on CMC media that had been dripped with congo red among the eleven isolates suspected to be cellulolytic bacteria. They were $\mathrm{S}_{10}, \mathrm{~S}_{2}, \mathrm{~S}_{3}, \mathrm{~S}_{11}$, and $\mathrm{S}_{4}$.
Nababan et al. (2019) reported that congo red dye will enter the agar medium because the substance is absorbed by polysaccharide chains that have $\beta$-D-glucan bonds. Rahmawati and Rafdinal (2017) state that the resulting cellulolytic index value is categorized as small to medium because IS is worth less than $1 \mathrm{~mm}$ (Rahmawati and Rafdinal, 2017). According to Murtiyaningsih and Hazmi, (2017), the largest IS was owned by an isolate of 6.1 whose chicken coop soil is about 1,533 $\mathrm{mm}$.

Table 2. Cellulolytic index of bacterial isolate

\begin{tabular}{cccc}
\hline $\begin{array}{c}\text { Isolate } \\
\text { codes }\end{array}$ & $\begin{array}{c}\text { Clear zone } \\
\text { diameter }\end{array}$ & $\begin{array}{c}\text { Colony } \\
\text { diameter }\end{array}$ & $\begin{array}{c}\text { Cellulolytic } \\
\text { index (mm) }\end{array}$ \\
\hline $\mathrm{S}_{2}$ & 33.68 & 20.38 & 0.6526 \\
$\mathrm{~S}_{3}$ & 30.74 & 19.50 & 0.5728 \\
$\mathrm{~S}_{4}$ & 29.41 & 19.78 & 0.4873 \\
$\mathrm{~S}_{5}$ & 32.22 & 25.68 & 0.4422 \\
$\mathrm{~S}_{6}$ & 36.34 & 25.68 & 0.4112 \\
$\mathrm{D}_{7}$ & 18.18 & 7.40 & 1.4567 \\
$\mathrm{~S}_{10}$ & 26.86 & 14.28 & 0.8809 \\
$\mathrm{~S}_{11}$ & 30.68 & 19.64 & 0.5621 \\
\hline
\end{tabular}

Percentage of Dry Mass Loss from Isolates of Bacteria

Five isolates had a higher clear zone, these isolates were indicated to degrade OPEFB. It can be seen in Figure 2 .

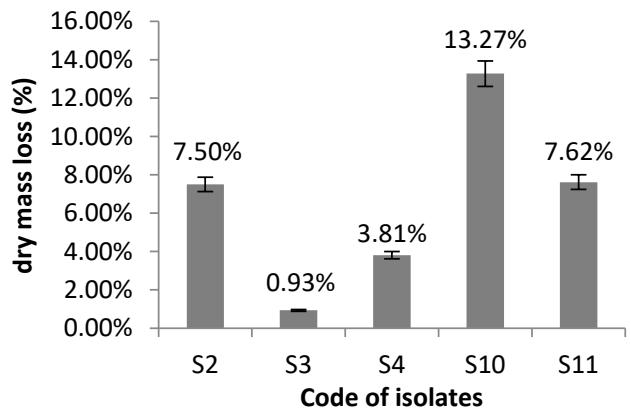

Figure 2. Percentage of dry mass from isolates of bacteria
Figure 2 showed that dry weight loss of $\mathrm{S}_{10}$ isolate was high value at $13.27 \%$ The percentage of degradation in this study is in the medium category. According to Arifin et al. (2019), the reduced final weight resulted in a smaller potential for degradation. Irawati (2017) reported that the degradation percentage of cellulose by bacteria reached 9.4\%-13.06\%. Ahmad and KumarKhare (2018) reported the degradation percentage of cellulose achieved $8 \%$. While Lu et al. (2018) reported that vegetable compost isolation could degrade filter paper with a percentage of about $26.3 \%, 24.5 \%$, and $19.4 \%$ after 14 days. Nababan et al. (2019) stated 
that the percentage of dry weight degradation obtained was $11.37 \%$ to $3.32 \%$.

Enzyme Activity of Bacteria

The measurement of the absorbance of reducing sugar was obtained by the equation $\mathrm{y}=2.4635 \mathrm{x}-0.1383$ with a value of $\mathrm{R}^{2}=$ 0.9987 . The activity of the cellulolytic enzyme can be seen in Table 3 .

Table 3. Activity of cellulase in bacterial isolate

\begin{tabular}{ccc}
\hline $\begin{array}{c}\text { Code } \\
\text { Isolates }\end{array}$ & $\begin{array}{c}\text { [glucose] } \\
\text { (mg/mL) }\end{array}$ & $\begin{array}{c}\text { Enzyme } \\
\text { activity } \\
\text { (U/mL) }\end{array}$ \\
\hline $\mathrm{S}_{2}$ & 0.5331 & 0.0493 \\
$\mathrm{~S}_{3}$ & 0.4210 & 0.0389 \\
$\mathrm{~S}_{4}$ & 0.3009 & 0.0278 \\
$\mathrm{~S}_{10}$ & 1.4135 & 0.308 \\
$\mathrm{~S}_{11}$ & 0.3910 & 0.0362 \\
\hline
\end{tabular}

The Activity of cellulase enzyme Using DNS Method

Measurement of enzyme activity using the DNS method has the same results as screening for cellulolytic bacteria using the measurement of the diameter of the clear zone. The results obtained from both methods showed that $S_{10}$ was found to possess cellulolytic activity as demonstrated by degradation of Carboxymethyl cellulose (CMC) and exhibited high cellulase enzyme activity compared to other isolates. Enzyme activity resulting from this research tends to be moderate to high. According to Nababan et al. (2019), the enzyme activity of crude extract from cellulolytic bacteria is in the moderate to high category. This can be seen from the activity value between $0.079 \mathrm{IU} / \mathrm{mL}$ to $0.069 \mathrm{IU} / \mathrm{mL}$, the percentage of dry weight degradation obtained is $11.37 \%$ to $3.32 \%$.

Mulyasari et al. (2015) obtained isolates from the digestive tract of gourami, crude extracts of these isolates can degrade the substrate from cassava leaves. The cellulase enzyme activity values obtained from isolates UG8, UG7, and UG3 were almost the same, namely
$0.104 \mathrm{U} / \mathrm{mL} ; 0.105 \mathrm{U} / \mathrm{mL}$; and $0.107 \mathrm{U} / \mathrm{mL}$. While Puspitasari and Ibrahim (2020) obtained bacterial isolates of EG2 which had been isolated from oil palm cake (Elaeis Guineensis Jacq), the enzyme activity obtained was $0.011 \mathrm{U} / \mathrm{mL}$.

\section{Conclusion}

The morphological character of microorganisms in degrading OPEFB was having a round colony shape, yellow color, convex elevation, and smooth and slippery surface, namely isolate $S_{10}$. The isolate has high potency in degrading OPEFB.

\section{Acknowledgment}

Authors give appreciation to the Laboratory of Biochemistry, Department of Chemistry, Faculty of Science, UIN Alauddin Makassar. The authors also would like to thank Fitria Azis and other technicians who helped us in finishing the research.

\section{Reference}

Ahmad, R., \& KumarKhare, S. (2018). Immobilization of Aspergillus niger cellulase on multiwall carbon nanotubes for cellulose hydrolysis. Bioresource Technology, 252, 72-75. https://doi.org/10.1016/j.biortech.20 17.12.082

Argo, B. D., \& Yulianingsih, R. (2013). Pemanfaatan Enzim Selulase dari Trichoderma Reseei dan Aspergillus Niger sebagai Katalisator Hidrolisis Enzimatik Jerami Padi dengan Pretreatment Microwave. Jurnal Bioproses Komoditas Tropis, 1(1), 3643.

Arifin, Z., Gunam, I. B. W., Antara, N. S., \& Setiyo, Y. (2019). Isolasi Bakteri Selulolitik Pendegradasi Selulosa Dari Kompos. Jurnal Rekayasa Dan Manajemen Agroindustri. https://doi.org/10.24843/jrma.2019.v 07.i01.p04 
Ekawati, E. R., Ni'matuzahroh, N., Surtiningsih, T., \& Supriyanto, A. (2012). Eksplorasi Dan Identifikasi Bakteri Selulolitik Pada Limbah Daduk Tebu (Saccharum Officinarum L). Berkala Penelitian Hayati, 18(1), 31-34. https://doi.org/10.23869/bphjbr.18.1. 20125

Ferbiyanto, A., Rusmana, I., \& Raffiudin, R. (2015). Characterization and Identification of Cellulolytic Bacteria from gut of Worker Macrotermes gilvus. HAYATI Journal of Biosciences, 1(9), $50-55$ https://doi.org/10.1016/j.hjb.2015.07 .001

Irawati, D. (2017). Hidrolisis Media Sisa Budidaya Jamur Kuping Menggunakan Tiga Jenis Enzim Selulase. Jurnal Ilmu Kehutanan, 2(3), 52-62.

Kholis, M. N., Asmediana, A., \& Sari, M. (2019). Potensi dan Karakterisasi Enzim Selulase Mikroba Asal Limbah Industri Minyak Kayu Putih. Agroindustrial Technology Journal, 3(2), 110-118.

Lu, S. H., Li, B. Q., Zhai, H. L., Zhang, X., \& Zhang, Z. Y. (2018). An effective approach to quantitative analysis of ternary amino acids in foxtail millet substrate based on terahertz spectroscopy. Food Chemistry, 246, 220-227. https://doi.org/10.1016/j.foodchem.2 017.11.016

Marina, Lambui, O., \& Nengah, S. (2018). Karakrerisasi Selulosa Asal Tanah Danau Kalimpa'a Sulawesi Tengah. Journal of Science and Technology, 7(2), 138-147.

Mulyasari, M., Widanarni, W., Suprayudi, M. A., Junior, M. Z., Sunarno, T. D., \& . 6, 111-121. (2015). Seleksi dan Identifikasi Bakteri Selulolitik yang Dapat Mendegradasi Serat Kasar Daun Singkong. $10(2)$. https://doi.org/10.15578/jpbkp.v10i2
.238

Murtiyaningsih, H., \& Hazmi, M. (2017). Isolasi dan Uji Aktivitas Enzim Selulase Pada Bakteri Selulolitik Asal Tanah Sampah. Agritop, 15(2), 293-308. http://jurnal.unmuhjember.ac.id/ index.php/AGRITROP.

Nababan, M., Gunam, I. B. W., \& Mahaputra Wijaya, I. M. (2019). Produksi Enzim Selulase Kasar Dari Bakteri Selulolitik. Jurnal Rekayasa Dan Manajemen Agroindustri, $\quad 7(2), \quad 190$. https://doi.org/10.24843/jrma.2019.v 07.i02.p03

Nofu, K., Khotimah, S., \& Irwan, L. (2014). Isolasi dan Karakteristik Bakteri Pendegradasi Selulosa pada Ampas Tebu Kuning (Bagasse). Jurnal Probiont, 3(1), 25-26.

Peristiwati, Natamihardja, Y. S., \& Herlini, H. (2018). Isolation and Identification of Cellulolytic Bacteria from Termites Gut (Cryptotermes sp.). Journal of Physics: Conference Series. https://doi.org/10.1088/17426596/1013/1/012173

Purkan, Purnama, H., \& Sumarsih, S. (2015). Produksi Enzim Selulase dari Aspergillus niger Menggunakan Sekam Padi dan Ampas Tebu sebagai Induser. Ilmu Dasar, 16(2), 95-102.

Puspitasari, D., \& Ibrahim, M. (2020). Optimasi Aktivitas Selulase Ekstraseluler Islolat Bakter EG 2 Isolasi dari Bungkil Kelapa Sawit (Elaesis guineensis jacq.). Lentera Bio, 9(1), 4250 .

Rahmasita, M. E., Farid, M., \& Ardhyananta, H. (2017). Analisa Morfologi Serat Tandan Kosong Kelapa Sawit Sebagai Bahan Penguat Komposit Absorpsi Suara. Jurnal Teknik ITS, 6(2). https://doi.org/10.12962/j23373539. v6i2.24332 
Rahmawati, R. D., \& Rafdinal. (2017). Eksplorasi Bakteri Selulolitik dari Tanah Hutan Mangrove. Protobiont, 6(3), 255-262.

Rawway, M., Ali, S. G., \& Badawy, A. S. (2018). Isolation and Identification of Cellulose Degrading Bacteria from Different Sources at Assiut Governorate (Upper Egypt). Journal of Ecology of Health \& Environmen, 6(1), 15-24. https://doi.org/10.18576/jehe/06010 3

Razie, F., Anas, I., Sutandi, A., Gunarto, L., \& Sugiyanta, S. (2011). Aktivitas Enzim Selulase Mikroba yang Diisolasi dari Jerami Padi di Persawahan Pasang Surut di Kalimantan Selatan. Jurnal Ilmu Tanah Dan Lingkungan, 13(2). https://doi.org/10.29244/jitl.13.2.4348

Rupaedah, B., Purwoko, D., Saffarida, A., Tajuddin, T., Wahid, A., Sugianto, M., Suja'i, I., \& Suyono, A. (2019). Skrining dan Identifikasi Mikroba Lignolitik pada Pengomposan Alami Tandan Kosong Kelapa Sawit. Bioteknologi Dan Biosains Indonesia, 6(1).

Supriyatna, A., Amalia, D., Agustini, J. A., \& Holydaziah, D. (2015). Aktivitas Enzim Amilase, Lipase, dan Protease dari Larva Hermetia illucens yang Diberi Pakan Jerami Padi. Jurnal Istek.
Talantan, V. M., Lambui, O., \& Suwastika, I. N. (2018). Uji Aktivitas Selulase Dari Jamur Selulolitik Asal Tanah Danau Kalimpa ' a Sulawesi Tengah Cellulase Activity Of Cellulolytic Fungi On Soil From Lake Kalimpa' a Central Sulawesi. Natura Science: Journal of Science and Technology, 7(3), 323-333.

Tarkono, \& Ali, H. (2015). Pengaruh Penambahan Serat Tandan Kosong Kelapa Sawit (TKKS) Terhadap Sifat Mekanik Eternit yang Ramah Lingkungan. Jurnal Teknologi, 8(1).

Yusnia, E. D., Wayan Gunam, I. B., \& Semadi Antara, N. (2019). Isolasi Dan Skrining Bakteri Selulolitik Dari Beberapa Tanah Hutan Di Bali. Jurnal Rekayasa Dan Manajemen Agroindustri, 7(1). https://doi.org/10.24843/jrma.2019.v 07.i01.p02 